\title{
TITLE:
}

\section{Ranging behavior of Mahale chimpanzees: a 16 year study.}

\section{$\operatorname{AUTHOR}(\mathrm{S}):$}

Nakamura, Michio; Corp, Nadia; Fujimoto, Mariko; Fujita, Shiho; Hanamura, Shunkichi; Hayaki, Hitoshige; Hosaka, Kazuhiko; ... Turner, Linda A; Wakibara, James V; Zamma, Koichiro

\section{CITATION:}

Nakamura, Michio ...[et al]. Ranging behavior of Mahale chimpanzees: a 16 year study.. Primates 2013, 54(2): 171-182

\section{ISSUE DATE:}

2013-04

URL:

http://hdl.handle.net/2433/173328

\section{RIGHT:}

The final publication is available at link.springer.com; This is not the published version. Please cite only the published version.; この論文は 出版社版でありません。引用の際には出版社版をご確認ご利用くださ い。 
NOTICE: This is the author's version of the following article.

Nakamura M, Corp N, Fujimoto M, Fujita S, Hanamura S, Hayaki H, Hosaka K, Huffman MA, Inaba A, Inoue E, Itoh N,

Kutsukake N, Kiyono-Fuse M, Kooriyama T, Marchant LF, Matsumoto-Oda A, Matsusaka T, McGrew WC, Mitani JC, Nishie

H, Norikoshi K, Sakamaki T, Shimada M, Turner LA, Wakibara JV, Zamma K (2013). Ranging behavior of Mahale chimpanzees: a 16 year study. Primates 54:171-182. DOI 10.1007/s10329-012-0337-z

(C) Japan Monkey Center and Springer.

\title{
Ranging behavior of Mahale chimpanzees: a 16 year study
}

\author{
MiCHIO NAKAMURA ${ }^{1}$, NADIA CORP ${ }^{2}$, MARIKO FUJIMOTO ${ }^{1}$, SHIHO FUJITA ${ }^{3}$, SHUNKICHI \\ HANAMURA $^{1}$, HitOSHige HAYAKI ${ }^{4}$, KAZUHiko HosAKA ${ }^{5}$, MiCHAEl A. HUfFMAN ${ }^{1}$, \\ AGUMI INABA ${ }^{6}$, EIJI INOUE ${ }^{1}$, NORIKO ITOH ${ }^{1}$, NOBUYUKI KUTSUKAKE ${ }^{7}$, MiEKO \\ KIYONO-FUSE ${ }^{8}$, TAKANORI KOORIYAMA ${ }^{6}$, LINDA F. MARCHANT ${ }^{9}$, AKIKO \\ MAtSumoto-Oda $^{10}$, TAKAhisa Matsusaka ${ }^{11}$, William C. McGreW ${ }^{12}$, John C. \\ MitANI $^{13}$, HitONARU NiSHIE ${ }^{1}$, KOSHI NORIKOSHI ${ }^{14}$, TETSUYA SAKAMAKI ${ }^{1}$, MASAKI \\ SHIMADA $^{15}$, LindA A. TURNER ${ }^{16}$, JAMES V. WAKIBARA ${ }^{17}$, KOICHIRO ZAMMA ${ }^{18}$
}

${ }^{1}$ Kyoto University, Japan; ${ }^{2}$ Keele University, UK; ${ }^{3}$ Kagoshima University, Japan; ${ }^{4}$ Kobe Gakuin University, Japan; ${ }^{5}$ Kamakura Women's University, Japan; ${ }^{6}$ Japan Monkey Centre, Japan; ${ }^{7}$ The Graduate University for Advanced Studies, Japan; ${ }^{8}$ Kobe University, Japan; ${ }^{9}$ Miami University, USA; ${ }^{10}$ University of the Ryukyus, Japan; ${ }^{11}$ Kansai University, Japan; ${ }^{12}$ University of Cambridge, UK; ${ }^{13}$ University of Michigan, USA; ${ }^{14}$ Sophia University, Japan; ${ }^{15}$ Teikyo University of Science, Japan; ${ }^{16}$ Frankford Hospital, USA; ${ }^{17}$ Tanzania National Parks, Tanzania; ${ }^{18}$ Hayashibara Great Ape Research Institute, Japan

This paper would not have been possible without the late Professors Toshisada Nishida, Kenji Kawanaka, and Shigeo Uehara, whose pioneering research at Mahale contributed substantially to the data reported here. Copyright issues preclude listing them posthumously as authors, though they deserve to be.

\begin{abstract}
We have analyzed the ranging patterns of the Mimikire group (M group) of chimpanzees in the Mahale Mountains National Park, Tanzania. During 16 years, the chimpanzees moved over a total area of 25.2 or $27.4 \mathrm{~km}^{2}$, as estimated by the grid-cell or minimum convex polygon (MCP) methods, respectively. Annually, the M group used an average of $18.4 \mathrm{~km}^{2}$, or approximately $70 \%$, of the total home-range area. The chimpanzees had used $80 \%$ of their total home range after 5 years and $95 \%$ after 11 years. M group chimpanzees were observed more than half of the time in areas that composed only $15 \%$ of their total home range. Thus, they typically moved over limited areas, visiting other parts of their range only occasionally. On average, the chimpanzees used $7.6 \mathrm{~km}^{2}$ (in MCP) per month. Mean monthly range size was smallest at the end of the rainy season and largest at the end of the dry season, but there was much variability from year to year. The chimpanzees used many of the same areas every year when Saba comorensis fruits were abundant between August and January. In contrast, the chimpanzees used several different areas of their range in June. Here range overlap between years was relatively small. Over the 16 years of the study we found that the $\mathrm{M}$ group reduced their use of the northern part of their range and increased their frequency of visits to the eastern mountainous side of their home range. Changes in home-range size correlated positively with the number of adult females but not with the number of adult males. This finding does not support a prediction of the male-defended territory model proposed for some East African chimpanzee unit-groups.
\end{abstract}

Keywords: Chimpanzee, Pan troglodytes, Home range, Mahale, Seasonality

\section{Introduction}

Chimpanzees (Pan troglodytes) eat mainly ripe fruits (Nishida and Uehara 1983). Because fruit is patchily distributed, they move relatively long distances every day to satisfy their nutritional requirements. Chimpanzees form multi-male, multi-female unit-groups (Nishida 1968) or communities (Goodall 1986) that consist of approximately 50 members. Unit-groups, 
however, can be as small as 12 individuals (Sugiyama and Fujita 2011) and as large as more than 180 chimpanzees (Mitani unpublished data). Members of unit-groups rarely forage together but usually split into smaller subgroups (Nishida 1968) or parties (Sugiyama 1968). Several different terms are used in the literature to describe the same forms of aggregation pattern of Pan species; this can lead to confusion (reviewed by Van Elsacker et al. 1995). Throughout this paper, we use the term "unit-group" to refer to the largest social group, corresponding to Level I of Van Elsacker et al. (1995) or "community" used by some researchers. When referring to a given unit-group with a proper noun, we just use the term "group", for example "Mimikire group". We use the term "party" for a lower level of flexible aggregation, basically corresponding to Level III of Van Elsacker et al. (1995). Itoh and Nishida (2007) distinguished two levels of party for Mahale chimpanzees: "face-to-face party" and "nomadic party". The former is a smaller aggregation and basically defined by visual contacts among members. The latter level is a larger aggregation, sometimes as large as the entire unit-group. Such a large aggregation is often found in a particular season at Mahale. Members in the nomadic party travel in approximately the same direction maintaining acoustic contact, but not always visual contact, with each other. Thus we use the term "nomadic party" (this may correspond to Level II of Van Elsacker et al. 1995) when specifically referring to these larger aggregations.

There is much variability in the home-range sizes of wild chimpanzees (Table 1). Chimpanzees in drier habitats, for example Ugalla (Ogawa et al. 2007), Fongoli (Pruetz 2006), Mt Assirik (Baldwin et al. 1982), and Kasakati (Izawa 1970), tend to move over large home-range areas of up to several hundred $\mathrm{km}^{2}$. Chimpanzees in some of these savanna habitats are unhabituated to human presence, and thus difficult to follow. As a consequence, some of these values are only approximate estimates based on calls or other indirect evidence. In more forested areas, range sizes are usually much smaller, varying from 5 to $40 \mathrm{~km}^{2}$ (Table 1). In all long-term study sites, home-range sizes seem to fluctuate across years. At Gombe, for example, home-range size decreased from $12 \mathrm{~km}^{2}$ in 1975-1978 to $5.4 \mathrm{~km}^{2}$ in 1979-1982 (Williams et al. 2002). In contrast, the Ngogo chimpanzees acquired an additional $6.4 \mathrm{~km}^{2}$ area in 2009 (Mitani et al. 2010).

The home range of a chimpanzee unit-group is often regarded as a "male community range" (Wrangham 1979) or a "male-defended boundary" (Williams et al. 2002). Thus changes in the home-range sizes are often explained by the number of males in the unit-group. One reason for this is that the home range of female chimpanzees is usually smaller than that of males (Wrangham and Smuts 1980). Another reason is that males show defensive behavior against neighboring unit-groups, for example boundary patrolling (Watts and Mitani 2001). They also sometimes engage in lethal inter-unit-group aggression (Manson and Wrangham 1991; Mitani et al. 2010). Thus, the home range of a chimpanzee unit-group is sometimes termed a "territory" (Boesch and Boesch-Achermann 2000; Herbinger et al. 2001; Mitani et al. 2010).

Several direct and indirect lines of evidence support the connection between the number of males and the home range size of chimpanzees. At Gombe, the number of males correlated positively with home-range size from the 1960s to the mid-1990s (Stanford 1999, p. 59). This observation is in agreement with Goodall (1986, p. 228), who argued that changes in home-range size were primarily the result of variation in the number of adult males. In the North group at Taï, a large decline in home-range size from 1992 to 1998 was related to the number of males rather than to the total number of individuals in the unit-group (Lehmann and Boesch 2003). The home-range size of the Ngogo chimpanzees also increased dramatically in 2009 (Mitani et al. 2010). Here it was suggested that the extremely large number of Ngogo males enabled them to successfully attack and kill members of a neighboring unit-group. Male numbers were thus implicated as an important factor affecting range expansion. Finally, the home-range size of the Kanyawara chimpanzees more than doubled from 1988-1991 (Chapman and Wrangham 1993) to 1996-1998 (Wilson et al. 2001). There were 8 adult males in the unit-group during the former period and 10-11 during the latter, an observation consistent with the hypothesis that male numbers affect home-range size.

Despite these data, additional studies indicate that changes in male numbers do not always affect the range sizes occupied by chimpanzees. For instance, the home range of the Gombe chimpanzees declined drastically between 1975-1978 and 1979-1982. However, this change was unrelated to variation in the number of males in the unit-group during these times (Williams et al. 2004). In addition, the Sonso group at Budongo expanded its range into areas previously occupied by neighbors without concomitant change of the number of males (Fawcett 2000, p. 170).

Because they are ripe-fruit specialists, chimpanzees alter use of their home range as a function of the location of fruiting trees. Doran (1997) showed that the Taï chimpanzees reduced their travel distance when figs were superabundant and during periods of fruit scarcity, when they switched to a more folivorous diet. In contrast, Boesch and Boesch-Achermann (2000, pp 130-132) showed that monthly range size and the pattern of use of the range changed little at Taï. This was because the chimpanzees there cover long distances each day all year round.

Chimpanzees at the Mahale Mountains in Tanzania have been observed since 1965, making this the second longest study of chimpanzees in the wild (Nishida 1968). Although previous research has provided some estimates of the home-range size of the Mahale chimpanzees (Kawanaka and Nishida 1977; Hasegawa 1987), there has been no systematic study of long-term changes in the home-range size of chimpanzees at Mahale. In this paper, we provide data regarding range use by the Mahale Mimikire group (M group). Specifi- 
cally, we focus on changes in range use and relate these changes to variation in the demographic composition of the unit-group and to seasonal changes.

\section{Methods}

Research site, subject, and period

We analyzed data for ranging of the Mahale $\mathrm{M}$ group chimpanzees (see Nishida 1990, 2012 for details of the research site) for 16 years from 1994 to 2009 (total of 3,537 days or a mean of 221.1 days per year). M group's size during this study period varied from 47 to 70 , where the number of adult males was 5-10 and the number of adult females was 16-23 (Nakamura and Nishida 2012). At Mahale, the rainy season typically starts in October and ends in May (Takasaki et al. 1990). The research site is on the eastern shore of Lake Tanganyika in western Tanzania. Altitude varies from ca $780 \mathrm{~m}$ above sea level at the lake shore to ca 2,460 $\mathrm{m}$ above sea level at the top of Mt Nkungwe, the highest peak in the Mahale massif. Most of the area within M group's range is relatively flat and lies below 1,000 m above sea level. However in 1994, we cut an observation trail higher up the mountain (ca 1,200 m) running from north to south. This enabled us to better observe chimpanzees when they climbed up to where researchers had previously given up observation. Thus although ranging data before 1994 are also available, we analyze here only the data after 1994, because it more accurately reflects the apes' use of the home range.

\section{Recording procedure}

When following $\mathrm{M}$ group chimpanzees, observers recorded the daily ranging route of their targeted individuals or party on a map and these maps were accumulated and pooled as shared data. Collection of ranging data was not completely standardized, given differences in observation method, duration of the day spent following them, and the different research focus of each researcher. However the quality of the data collected is enough to create a picture of longerterm changes. Whenever possible, we recorded the ranging route of the party that included the alpha male, but when his travel route was uncertain, we recorded the route of others in the party under observation. Thus, in this analysis, the home range included places where at least some $\mathrm{M}$ group chimpanzees were seen. Researchers recorded the ranging route relative to the location of observers' trails and valleys. Measurement of the observation trails was conducted in the 1980s with accuracy such that when we re-measured some trails by use of GPS, the errors were usually within $30 \mathrm{~m}$ (Nakamura unpublished data).

\section{Estimation of home-range size}

For this analysis, we divided the ranging map into 250 $\mathrm{m} \times 250 \mathrm{~m}$ grids. When the ranging route on a given day passed through any part of a 250 -m grid, we considered that chimpanzees used the grid. When the route re-entered the same grid after use of a different grid, we counted use of the grid twice. Although several methods have been used to estimate home-range size, the minimum convex polygon (MCP) method and grid-cell method are commonly used in chimpanzee studies. The former is most convenient for comparison across sites (Newton-Fisher 2003). In the gridcell method, range size is calculated simply by summing the area of $250-\mathrm{m}$ cells that were used at least once during a given period. In the MCP method, we a priori considered that the chimpanzee used the center of a 250-m grid, and home-range size was thus calculated as the area of the convex polygon drawn by connecting the centers of the outermost grids. We calculated range sizes using both the grid-cell method and the MCP method, monthly, annually, and for the entire 16-year study period.

\section{Definitions}

High-use area: Fewest grids that account for $50 \%$ of the total number of grids used (including multiple uses of a grid) in a given period. We also calculated the MCP size of this high-use area.

Barycenter: Mean coordinates of all grids used (including multiple uses of a grid) in a given period.

Overlap index: To see grid use overlap in the same month in different years, the "overlap index" is defined as follows:

$$
\text { Overlap Index }=\left(\sum_{i=1}^{N} x_{i}-N\right) /(Y-1) N
$$

Here we only consider whether grid $i$ is used or not in a given month. $Y$ is the total observation years, $x_{i}$ is the number of years that grid $i$ was used (thus the range is 1 to $Y$ ), and $N$ is the total number of grids used at least once during $Y$ years. Therefore this index ranges from 0 (all $x_{i}$ is 1 , no overlap at all in $Y$ years) to 1 (all $x_{i}$ is $Y$, complete overlap).

Saba season: Former studies have emphasized the importance of Saba comorensis fruits at Mahale (Turner 2006; Itoh and Nishida 2007; Nishida 2012). Saba is a large liana species that sometimes spans the crowns of several trees. Among all M group's plant foods, this species grows at the highest density within their home range (Itoh et al. 2012). According to phenology study data (Itoh 2004), Saba fruits are available at high density from August to January and are an important food during this period (Nishida 2012, p. 35). Thus August to January is defined as the "Saba season" and the other months as the "non-Saba season".

We also divided all grids used during the entire 16-year study period into 6 blocks (Fig. 1) and looked at differences in their use across years and months.

F (Far north): Northernmost (block) area of the home range located north of Mpila Valley. The area had been exclusively used by $\mathrm{M}$ group after the extinction of Kagimimi group (K group) in the 1980s (Nishida et al. 1985), however in the late 1990s another unit-group, 
the Miyako group (Y group), began to use this area (Uehara 2002; Sakamaki et al. 2007). Currently this area overlaps the range of $\mathrm{M}$ and $\mathrm{Y}$ groups.

$\mathrm{N}$ (North): South of Mpila valley and north of Kansyana valley. There is a hill between these two valleys and the terrain undulates although overall the altitude is not high. The Y group chimpanzees seldom enter this block but when they vocalize in the F block they can be heard from the top of this hill.

M (Middle): Relatively flat with a well-developed semievergreen forest (Kasoje Forest). The area is used almost exclusively by $\mathrm{M}$ group.

W (West): Along the shore of Lake Tanganyika. Relatively flat with deciduous Miombo woodland. Exclusively used by $\mathrm{M}$ group. Former village settlements and, currently, tourist camps are in this block.

E (East): Steep slopes rising toward the Mahale Mountains, basically higher than $1,000 \mathrm{~m}$. An unknown unit-group was once seen to enter this area (Itoh et al. 1999).

S (South): South of the Lubulungu River. It is the largest river within the range of the $\mathrm{M}$ group, and when it is flooded the chimpanzees sometimes cannot cross it. Relatively flat with no well-developed forests. Overlapping area with $\mathrm{N}$ 'ganja group ( $\mathrm{N}$ group) to the south (Shimada 2003).

\section{Results}

Home-range size and changes over 16 years

Over 16 years, M group chimpanzees used $25.2 \mathrm{~km}^{2}$ by the grid-cell method and $27.4 \mathrm{~km}^{2}$ by the MCP method (Fig. 1). Figure 2 shows the change of annual home-range sizes by MCP and Fig. 3 shows the grids used in these 16 years. Mean annual MCP range size was $18.4 \mathrm{~km}^{2}( \pm 2.56 \mathrm{SD})$. This is $66.9 \%$ of the 16 -year range, from the smallest at $13.9 \mathrm{~km}^{2}(50.7 \%)$ in 1999 to the largest at $22.2 \mathrm{~km}^{2}(81.0 \%)$ in 2001 . Range size seems to have decreased in 1996-2000, soon after the most catastrophic decrease observed in M group's size since the beginning of the research (Nishida et al. 2003). However, it increased again after 2001, and the difference between 1996-2000 and the other years was significant (Wilcoxon rank sum test, $\mathrm{N}_{1}=5, \mathrm{~N}_{2}=11$, $\mathrm{W}=0, \mathrm{p}<0.01)$. As the number of researchers visiting Mahale per year did not differ between these two periods $\left(\mathrm{N}_{1}=5, \mathrm{~N}_{2}=11, \mathrm{~W}=24.5, \mathrm{p}=0.77\right)$, any differences between years cannot be attributed simply to different research effort in different years. For high-use area sizes (Fig. 2, dotted line), the MCP mean over 16 years was limited to $4.3 \mathrm{~km}^{2}( \pm 1.03 \mathrm{SD})$, which is $15.7 \%$ of the total range size. Although the annual home-range size and pattern fluctuated, $\mathrm{M}$ group did not seem to shift or to change greatly its range use over the 16 years (Fig. 3). This concurs with data that show annual barycenters over 16 years to be concentrated in a small area, with the mean distance between them being only $0.47 \mathrm{~km}( \pm 0.33 \mathrm{SD})$ and the largest being $1.42 \mathrm{~km}$. The barycenters all fell within a $0.34-\mathrm{km}$-wide band in the east-west axis and within a 1.42-km-wide band in the north-south axis. However, there was a slight shift southward as the barycenter moved south following the years (Kendall's rank correlation test, $\mathrm{s}=$ $0.55, \mathrm{~N}=16, \mathrm{p}<0.05$ ).

The accumulated area of the range (in grid-cells) reached only approximately $70 \%$ of the overall home range in the first year, and there was little increase in the second year (Fig. 4). Even after 5 years, the cumulative area was only about $80 \%$ of the total, and it reached $95 \%$ only after 11 years. A new place was used even in the 16th year.

For changes in block use, it seems that $\mathrm{N}$ and $\mathrm{F}$ blocks declined in recent years (Fig. 5). Proportion of use of $\mathrm{N}$ and $\mathrm{F}$ blocks negatively correlated with year (s $=-0.63, \mathrm{~N}=16, \mathrm{p}<0.001$ ). No significant correlation with year was found for other blocks, but the number of months that chimpanzees visited the grids in E block more than 10 times increased significantly by year ( $\mathrm{s}=$ $0.57, \mathrm{~N}=16, \mathrm{p}<0.01)$.

\section{Demography and range size}

Annual range size correlated positively with total number of individuals in any given year $(\mathrm{s}=0.45, \mathrm{~N}=16$, $\mathrm{p}<0.05$ ). By age-sex class, annual range size correlated best with the number of adult females $(\mathrm{s}=0.47$, $\mathrm{N}=16, \mathrm{p}<0.05$ ) and also positively correlated with the number of immature individuals $(\mathrm{s}=0.46, \mathrm{~N}=16$, $\mathrm{p}<0.05$ ). However, there was no correlation with the number of adult males $(\mathrm{s}=0.22, \mathrm{~N}=16, \mathrm{p}=0.26)$.

\section{Monthly range and seasonality}

On average, $\mathrm{M}$ group chimpanzees used $7.6 \mathrm{~km}^{2}( \pm 3.13$ SD) per month. However, in the month of greatest use (August 2001), they used an area of $17.3 \mathrm{~km}^{2}$. This exceeded even the annual range size in some years. Mean range size was smallest in April at the end of the rainy season and largest in August at the end of the dry season (Table 2), but not all years followed this pattern. The overlap index was smallest in June and largest in October (Table 2), which means that $\mathrm{M}$ group tended to use different places in June. In the Saba season, however, mean range size was larger (Wilcoxon rank sum test, $\left.\mathrm{N}_{1}=6, \mathrm{~N}_{2}=6, \mathrm{~W}=3, \mathrm{p}<0.05\right)$ and overlap index was greater $\left(\mathrm{N}_{1}=6, \mathrm{~N}_{2}=6, \mathrm{~W}=0, \mathrm{p}<0.01\right)$ than those for the non-Saba season. Also, the mean distance of barycenters was smaller $\left(\mathrm{N}_{1}=6, \mathrm{~N}_{2}=6, \mathrm{~W}=35\right.$, $\mathrm{p}<0.01$ ) in the former than in the latter.

For average monthly use of the blocks (Fig. 6), chimpanzees most often used the M block in any given month, but the proportion differed month by month. This may be related to the stability of the ranging pattern of the month, i.e., June, the month with least use of the $\mathrm{M}$ block, was also the month with smallest overlap index. Also, the mean distance of barycenters in June was $1.64 \mathrm{~km}( \pm 1.13 \mathrm{SD})$, which was the greatest for all months (Table 2). The distance between barycenters for June 1998 and June 2009, especially, was largest 
$(5.46 \mathrm{~km})$ of all, and this was more than half of the longer diameter of the range. In December, however (when use of $\mathrm{M}$ block is the highest), although the overlap index was not the largest, the mean distance of barycenters was the smallest for all the months.

\section{Discussion}

Long-term change of range use

The home-range size of the Mahale $\mathrm{M}$ group is well within the range of variation of other populations of chimpanzees' home ranges (Table 1). Their current range size is similar to that calculated in the 1980s (Hasegawa 1987), implying stability of home-range size over long time spans.

Yet annual home-range size also fluctuated at Mahale, as reported at several research sites. The ratio of least range size to the most was $63 \%$ $\left(13.9 \mathrm{~km}^{2} / 22.2 \mathrm{~km}^{2}\right)$ in Mahale. Comparable values from other study sites are $45 \%(5.4 / 12)$ at Gombe (Williams et al. 2002), 39\% (14.9/37.8) at Kanyawara (Chapman and Wrangham 1993; Wilson et al. 2001), 82\% (28.5/35.2) at Ngogo (Mitani et al. 2010), 70\% (6.8/9.7) at Budongo (Fawcett 2000; Newton-Fisher 2003), and 53\% (13.9/26.4) at Taï North (Lehmann and Boesch 2003). Although there may be several reasons for variation across years, all of these long-studied unit-groups experienced $39-82 \%$ change. Thus, it is usual for chimpanzees to increase their annual range size by up to twice or reduce it by half. The data from Mahale showed that they typically used only $70 \%$ of total home range in a year, and 95\%-use was achieved only after 11 years. This suggests that a one-year period is too short to estimate chimpanzees' potential home-range size, and some areas in the home range are not visited in a given year.

No apparent shift in range-use appeared in these 16 years, because the mean barycenter distance was less than $500 \mathrm{~m}$, which is only $5 \%$ of the longer dimension of the range. This may be comparable with a less than $300 \mathrm{~m}$ shift ( $6 \%$ of the diameter) in Taï over 13 years (Boesch and Boesch-Achermann 2000, p. 133). The high-use area that covered $50 \%$ of their utilization took up only $15 \%$ of total home range. Also the fluctuation of the annual size of the high-use area was very small. These results imply that $M$ group routinely uses very limited and similar areas in concentration but it uses other places in their home range over a long time span.

\section{Change of block use}

Use of the two most northerly blocks gradually decreased year by year, which is consistent with the yearly barycenter gradually moving southward. This may be related to the existence of an unknown neighboring unit-group to the north, called the $\mathrm{Y}$ group, whose existence was confirmed early in the late 1990s (Sakamaki and Nakamura 2007; Sakamaki et al. 2007). Although the Y group is not yet habituated, it often uses the F block, and when they vocalize it is easily heard from a hill in N block. However, we assume the $\mathrm{Y}$ group is smaller than the $\mathrm{M}$ group, because the $\mathrm{Y}$ group less often vocalized and because the $\mathrm{Y}$ group moved northward when M group's vocalizations approached from the south. Attack on an unknown infant (probably of a $\mathrm{Y}$ group female) by the $\mathrm{M}$ group chimpanzees was also observed in F block in December, 2000 (Kutsukake and Matsusaka 2002). Judging from these observations, it seems the $\mathrm{M}$ group is dominant over the $\mathrm{Y}$ group so there is no obvious reason for $\mathrm{M}$ group to avoid Y group. However, if enough food is available in southern parts and if there is even a small risk to encounters, then chimpanzees may reduce their use of overlapping areas irrespective of the dominance relationships between unit-groups.

The E block (mountainous area) seems to have been visited more frequently recently. This may be because of changes in vegetation in the lower areas. After Mahale was designated a national park in 1985, local people who used to live near the lakeshore moved out of the park, abandoning some crop fields. Thus, the vegetation of lowland areas recovered over succeeding decades; the former grassland and bushes (abandoned field and settlement) are now mature forest. This succession may have reduced some of the chimpanzee food-items in this area. For example, an important food Harungana madagascariensis was seen commonly in the 1990s in secondary forests after human disturbance, especially near the lakeshore. As a consequence of succession, we see few of this species in the same place. Another possible reason for more frequent visiting is the recent absence of a neighboring unit-group to the east. In 1998, an unknown unit-group made incursions into E block (Itoh et al. 1999) but this unit-group has not been seen again since then. In contrast with the northern blocks, we believe the $\mathrm{M}$ group more frequently visits the $\mathrm{E}$ block because of the absence of a neighboring unit-group there.

\section{Demography and range size}

Changes in the annual range size at Mahale were positively correlated with unit-group size. This positive correlation is likely to be a result of a large decrease in range size after 1996, when as many as 25 individuals disappeared for unknown reason (Nishida et al. 2003). After 2001, their range size returned to its former size, as unit-group size began to increase again. Interestingly, these changes in range size correlated best with the number of adult females in the unit-group, but did not correlate with the number of adult males. This result contrasts with those from some previous studies in which the number of males was the best predictor of changes of range size (Gombe: Stanford 1999; Таї: Boesch and Boesch-Achermann 2000, p. 134; Lehmann and Boesch 2003). It also differs from results showing no correlation between the number of females and range size (Gombe: Williams et al. 2004; Taï: Boesch and Boesch-Achermann 2000). A lack of correlation does not disprove the male-defended boundary hypothesis because the number of males is a relative issue (Williams et al. 2004). Also the smaller number of adult males than any other age-sex class may have prevented the correlation from reaching statistical signifi- 
cance for males. However, our findings suggest that females were more responsible for range size at Mahale.

In Mahale, at least in the Saba season, chimpanzees form large nomadic parties including both males and females (Itoh and Nishida 2007) and range widely from north to south. Most of the unit-group members commonly reach peripheral areas of the range in this season. For example, on October 17, 2004, M group reached the second northernmost grids, traveling in a large nomadic party of 53 of 58 members, including mothers and infants. Similarly, on October 14, 2008, they reached the second southernmost grids with at least 44 of 61 members (Nakamura, personal observation), although this number may be underestimated because of bad observation conditions. These grids were far inside the overlapping areas with neighboring unit-groups to the north and the south, respectively.

Such ranging characteristics at Mahale contrast notably with some other East African chimpanzee study sites. Females stay in far smaller core areas at Gombe (Wrangham 1979) and Kanyawara (Chapman and Wrangham 1993), and females rarely visit boundary areas that overlap with those of neighboring unit-groups (Chapman and Wrangham 1993). Ranging at Mahale in the Saba season may resemble more closely Taï, where females utilize $90 \%$ of the males' range (Lehmann and Boesch 2005) or Budongo, where the males' range area totally overlaps that of the females (Fawcett 2000). Such bisexual aspects of ranging and the importance of Saba to their ranging in the Saba season agrees with claims in previous reports from Mahale (Uehara 1981; Kawanaka 1984; Hasegawa 1990).

Unlike fruiting trees that have a more patchy distribution, Saba fruits are more widely distributed because this large liana often spans the crowns of several trees and is extraordinary high in its density throughout the study area at Mahale (Itoh et al. 2012). Thus chimpanzees feeding on Saba sometimes spread over several hundreds of meters but maintain their overall ranging direction (Itoh and Nishida 2007). Saba is abundant but not restricted to a particular patch. Because of this characteristic of Saba, chimpanzees of M group may change their range sizes according to the number of females joining the large nomadic party.

\section{Seasonality}

Home-range size at Mahale was, on average, smallest in April and largest in August. This seems to correspond approximately with the availability of food resources. In April, few fruits are available (Itoh 2004), so $\mathrm{M}$ group chimpanzees often spread out and range in small parties. However, in such seasons, observation is mostly concentrated on relatively large parties that use the central area of the home range. It is often difficult to find some individuals who range in small parties, because they do not usually vocalize, especially when they range in peripheral areas. Thus, use of such peripheral areas by small parties may be underestimated. On the other hand, August is the beginning of the Saba season and chimpanzees begin to gather together and range in a large nomadic party from north to south. In some years such peaks do not follow this pattern. This may be largely because of the availability of the fruits in the given year. However, we should also take into consideration different research efforts and the targets the researchers were following in that particular year.

Overlap across years was significantly larger in the Saba season than in the non-Saba season. So, in the Saba season M group chimpanzees tended to use similar areas every year whereas in the non-Saba season they tended to use different areas in different years, and even stayed in peripheral areas, probably following the different fruit species available. For example, instability of range use was most evident in June when the overlap of range use was smallest. In June 1994, chimpanzees mainly utilized Harungana madagascariensis near the lakeshore (Nakamura, personal observation). But in June 1998, they used abundant Mimusops bagshawei in the northern most area of their home range (Itoh et al. 1999; Itoh 2004). In June 2009, they ate Canthium rubrocostatum and Toddalia asiatica in the southern part of higher-altitude areas (Nakamura, personal observation). Thus, even in the same month, they used completely different places and the largest barycenter distance was observed between June 1998 and June 2009. Such obvious seasonal differences of ranging differ from that reported at Taï, where range utilization was not strongly seasonal and there was no major shift in the center of activity or a shift in the areas used (Boesch and Boesch-Achermann 2000; Herbinger et al. 2001). The Saba season in Mahale may be similar to the characteristic of Taï chimpanzees' ranging with no large shift in activity centers and relatively long distances traveled in a day. However, in the non-Saba season, they may concentrate more on patchily distributed food species that may differ year by year. Consequently, range size becomes smaller within a year but the areas used may differ from year to year. Such alternation of stable/wide ranging and unstable/small ranging in different seasons may be responsible for the unique characteristics of Mahale’s chimpanzees.

\section{Implications for future research}

Our initial purpose in writing this paper was to quantitatively present basic information about the ranging behavior of Mahale chimpanzees. However, our results also provided several new areas for future research.

First, our results, for the first time, suggested the likely importance of females in home-range size variation. Thus further research is needed to investigate females' participation in the formation of a unit-group and the maintenance of its home range. Second, although inter-unit-group relationships seemed to affect changes in range use at Mahale, it may not simply be explained by dominant-subordinate relationships between two unit-groups. We need to investigate what other factors affect the changes in range use. Finally, the existence of a highly available species, Saba comorensis, seemed to substantially affect the ranging behavior of Mahale chimpanzees. Long-term monitor- 
ing of such unique chimpanzee-plant relationships and more detailed analysis of phenological change of such specific plant species will also be essential for better understanding of the ranging behavior of chimpanzees.

\section{Acknowledgments}

We thank the Tanzania Commission for Science and Technology, Tanzania National Parks, Tanzania Wildlife Research Institute, Mahale Mountains National Park, and Mahale Mountains Wildlife Research Centre for permission to do research in Mahale. The late Professors Toshisada Nishida, Kenji Kawanaka, and Shigeo Uehara initiated fieldwork on the Mahale chimpanzees and supplied their long-term observations for use in this paper. We are grateful for their contributions to the data set and for their long-term leadership of the research project at Mahale. We also thank Dr C. Hashimoto and an anonymous reviewer for comments on the manuscript. This study was financially supported by MEXT Grants-in-Aid (KAKENHI) (12375003, 16255007, 19255008 to TN, 19107007 to J Yamagiwa, and 21770262 to $\mathrm{MN}$ ).

\section{References}

Baldwin PJ, McGrew WC, Tutin CEG (1982) Wide-ranging chimpanzees at Mt. Assirik, Senegal. Int J Primatol 3:367-385

Boesch C, Boesch-Achermann H (2000) The chimpanzees of the Taï forest. Oxford University Press, Oxford

Chapman CA, Wrangham RW (1993) Range use of the forest chimpanzees of Kibale: implication for the understanding of chimpanzee social organization. Am J Primatol 31:263-273

Doran D (1997) Influence of seasonality on activity patterns, feeding behavior, ranging and grouping patterns in Taï chimpanzees. Int J Primatol 18:183-206

Fawcett KA (2000) Female relationships and food availability in a forest community of chimpanzees. PhD thesis, University of Edinburgh, Edinburgh

Goodall J (1986) The chimpanzees of Gombe. Harvard University Press, Cambridge

Hasegawa T (1987) Sexual behavior of wild chimpanzees: a comparative psychological study. PhD thesis, University of Tokyo (in Japanese)

Hasegawa T (1990) Sex differences in ranging patterns. In: Nishida T (ed) The chimpanzees of the Mahale Mountains. University of Tokyo Press, Tokyo, pp 99-114

Herbinger I, Boesch C, Rothe H (2001) Territory characteristics among three neighboring chimpanzee communities in the Taï National Park, Côte d'Ivoire. Int J Primatol 22:143-167

Humle T (2011) Location and ecology. In: Matsuzawa T, Humle T, Sugiyama Y (eds) The chimpanzees of Bossou and Nimba. Springer, Tokyo, pp 13-21

Itoh N (2004) Plant phenology and fission-fusion of chimpanzees at the Mahale Mountains National Park. Doctoral thesis, Kyoto University, Kyoto (in Japanese)

Itoh N, Nishida T (2007) Chimpanzee grouping patterns and food availability in Mahale Mountains National Park,
Tanzania. Primates 48:87-96

Itoh N, Sakamaki T, Hamisi M, Kitopeni R, Bunengwa M, Matumula M, Athumani K, Mwami M, Bunengwa H (1999) A new record of invasion by an unknown unit-group into the center of $\mathrm{M}$ group territory. Pan Afr News 6:8-10

Itoh N, Nakamura M, Ihobe H, Uehara S, Zamma K, Pintea L, Seimon A, Nishida T (2012) Long-term changes in the social and natural environments surrounding the chimpanzees of the Mahale Mountains National Park. In: Plumptre AJ (ed) The ecological impact of long-term changes in Africa's Rift Valley. NOVA Science, New York, pp 249-277

Izawa K (1970) Unit groups of chimpanzees and their nomadism in the savanna woodland. Primates 11:1-46

Kawanaka K (1984) Association, ranging, and the social unit in chimpanzees of the Mahale Mountains, Tanzania. Int J Primatol 5:411-434

Kawanaka K, Nishida T (1977) Chimpanzees of the Mahale Mountains (II): intergroup relationships between unit groups. In: Itani J (ed) The chimpanzees. Kôdan-sha, Tokyo (in Japanese)

Kutsukake N, Matsusaka T (2002) Incident of intense aggression by chimpanzees against an infant from another group in Mahale Mountains National Park, Tanzania. Am J Primatol 58:175-180

Lehmann J, Boesch C (2003) Social influences on ranging patterns among chimpanzees (Pan troglodytes verus) in the Taĩ National Park, Côte d'Ivoire. Behav Ecol 14:642-649

Lehmann J, Boesch C (2005) Bisexually bonded ranging in chimpanzees (Pan troglodytes verus). Behav Ecol Sociobiol 57:525-535

Manson JH, Wrangham RW (1991) Intergroup aggression in chimpanzees and humans. Curr Anthropol 32:369-390

Mitani JC, Watts DP, Amsler SJ (2010) Lethal intergroup aggression leads to territorial expansion in wild chimpanzees. Curr Biol 20:R507-R508

Nakamura M, Nishida T (2012) Long-term field studies of chimpanzees at Mahale Mountains National Park, Tanzania. In: Kappeler PM, Watts DP (eds) Long-term studies of primates. Springer, Heidelberg, pp 339-356

Newton-Fisher NE (2003) The home range of the Sonso community of chimpanzees from the Budongo Forest, Uganda. Afr J Ecol 41:150-156

Nishida T (1968) The social group of wild chimpanzees in the Mahali Mountains. Primates 9:167-224

Nishida T (1979) The social structure of chimpanzees of the Mahale Mountains. In: Hamburg DA, McCown ER (eds) The great apes. Benjamin/Cummings, Menlo Park, pp 73-121 Nishida T (ed) (1990) The chimpanzees of the Mahale Mountains. University of Tokyo Press, Tokyo

Nishida T (2012) Chimpanzees of the lakeshore. Cambridge University Press, Cambridge

Nishida T, Uehara S (1983) Natural diet of chimpanzees (Pan troglodytes schweinfurthii): long-term record from the Mahale Mountains, Tanzania. Afr Study Monogr 3:109-130

Nishida T, Hiraiwa-Hasegawa M, Hasegawa T, Takahata Y (1985) Group extinction and female transfer in wild chimpanzees of the Mahale Mountains. Z Tierpsychol 
67:284-301

Nishida T, Corp N, Hamai M, Hasegawa T, Hiraiwa-Hasegawa M, Hosaka K, Hunt KD, Itoh N, Kawanaka K, Matsumoto-Oda A, Mitani JC, Nakamura M, Norikoshi K, Sakamaki T, Turner L, Uehara S, Zamma K (2003) Demography, female life history, and reproductive profiles among the chimpanzees of Mahale. Am J Primatol 59:99-121

Ogawa H, Idani G, Moore J, Pintea L, Hernandez-Aguilar A (2007) Sleeping parties and nest distribution of chimpanzees in the savanna woodland, Ugalla, Tanzania. Int J Primatol 28:1397-1412

Pruetz J (2006) Feeding ecology of savanna chimpanzees (Pan troglodytes verus) at Fongoli, Senegal. In: Boesch C, Hohmann G, Robbins M (eds) The feeding ecology of great apes and other primates. Cambridge University Press, Cambridge, pp 161-182

Sakamaki T, Nakamura M (2007) Preliminary survey of unhabituated chimpanzees in the Mahale Mountains National Park, Tanzania: behavioral diversity across neighboring unit-groups and intergroup relationships. In: Formation of a strategic base for biodiversity studies. The 21st Century COE Program of Kyoto University, Kyoto, pp 278-280

Sakamaki T, Nakamura M, Nishida T (2007) Evidence of cultural differences in diet between two neighboring unit groups of chimpanzees in Mahale Mountains National Park, Tanzania. Pan Afr News 14:3-5

Shimada M (2003) A note on the southern neighboring groups of M group in the Mahale Mountains National Park. Pan Afr News 10:11-14

Stanford CB (1999) The hunting apes. Princeton University Press, Princeton

Sugiyama Y (1968) Social organization of chimpanzees in the Budongo Forest, Uganda. Primates 9:225-258

Sugiyama Y, Fujita S (2011) The demography and reproductive parameters of Bossou chimpanzees. In: Matsuzawa $\mathrm{T}$, Humle T, Sugiyama Y (eds) The chimpanzees of Bossou and Nimba. Springer, Tokyo, pp 23-34
Takasaki H, Nishida T, Uehara S, Norikoshi K, Kawanaka K, Takahata Y, Hiraiwa-Hasegawa M, Hasegawa T, Hayaki H, Masui K, Huffman MA (1990) Summary of meteorological data at Mahale research camps, 1973-1988. In: Nishida T (ed) The chimpanzees of the Mahale Mountains. University of Tokyo Press, Tokyo, pp 291-300

Turner LA (2006) Vegetation and chimpanzee ranging in the Mahale Mountains National Park, Tanzania. Mem Fac Sci Kyoto Univ (Ser Biol) 18:45-82

Uehara S (1981) The social unit of wild chimpanzees: a reconsideration based on the diachronic data accumulated at Kasoje in the Mahale Mountains, Tanzania. J Afr Stud 20:15-32 (in Japanese with English summary)

Uehara S (2002) Evidence of the leaf-clipping behavior by a chimpanzee of an unhabituated group at Mahale. Pan Afr News 9:3-4

Van Elsacker L, Vervaecke H, Verheyen RF (1995) A review of terminology on aggregation patterns in bonobos (Pan paniscus). Int J Primatol 16:37-52

Watts DP, Mitani JC (2001) Boundary patrols and intergroup encounters in wild chimpanzees. Behaviour 138:299-327

Williams JM, Pusey AE, Carlis JV, Farm BP, Goodall J (2002) Female competition and male territorial behaviour influence female chimpanzees' ranging patterns. Anim Behav 63:347-360

Williams JM, Oehlert GW, Carlis JV, Pusey AE (2004) Why do male chimpanzees defend a group range? Anim Behav 68:523-532

Wilson ML, Hauser MD, Wrangham RW (2001) Does participation in intergroup conflict depend on numerical assessment, range location, or rank for wild chimpanzees? Anim Behav 61:1203- 1216

Wrangham RW (1979) Sex differences in chimpanzee dispersion. In: Hamburg DA, McCown ER (eds) The great apes. Benjamin/ Cummings, Menlo Park, pp 481-489

Wrangham RW, Smuts BB (1980) Sex differences in the behavioural ecology of chimpanzees in the Gombe National Park, Tanzania. J Reprod Fertil Suppl 28:13-31 
Table 1 Comparison of wild chimpanzees’ home-range sizes

\begin{tabular}{|c|c|c|c|c|c|}
\hline Unit-group & $\begin{array}{c}\text { Home range } \\
\text { size }\left(\mathrm{km}^{2}\right)\end{array}$ & Method $^{\mathrm{b}}$ & Study year & $\begin{array}{l}\text { Grid size } \\
\text { (m) }\end{array}$ & Source \\
\hline Gombe $\mathrm{KK}^{\mathrm{a}}$ & 24 & GC? & $1960 \mathrm{~s}$ & $500 \times 500 ?$ & Goodall 1986 \\
\hline \multirow[t]{3}{*}{ Gombe Kasakela } & 9.6 & GC? & & $500 \times 500 ?$ & Goodall 1986 \\
\hline & 13 & GC & 1972 & $500 \times 500$ & Wrangham 1979 \\
\hline & $5.4-12$ & $99 \% \mathrm{MCP}$ & $\begin{array}{l}4 \text { yr periods be- } \\
\text { tween } \\
\text { 1975-1992 }\end{array}$ & & Williams et al. 2002 \\
\hline Gombe Kahama & 10 & GC & 1972 & $500 \times 500$ & Wrangham 1979 \\
\hline \multirow[t]{2}{*}{ Kibale Kanyawara } & 14.9 & MCP & 1988-1991 & $200 \times 200$ & $\begin{array}{l}\text { Chapman and } \\
\text { Wrangham } 1993\end{array}$ \\
\hline & 37.8 & MCP & 1996-1998 & $500 \times 500$ & Wilson et al. 2001 \\
\hline \multirow[t]{2}{*}{ Kibale Ngogo } & 28.8 & MCP & 1999-2008 & & Mitani et al. 2010 \\
\hline & 35.2 & MCP & 2009 & & Mitani et al. 2010 \\
\hline \multirow[t]{2}{*}{ Budongo Sonso } & 6.8 & MCP & 1994-1995 & $25 \times 25$ & Newton-Fisher 2003 \\
\hline & 9.7 & MCP & 1997-1998 & $100 \times 100$ & Fawcett 2000 \\
\hline \multirow[t]{3}{*}{ Taï North } & 16.5-26.9 & MCP & $\begin{array}{l}\text { Autumn 1982, } \\
1989 \text { and } 1995\end{array}$ & & $\begin{array}{l}\text { Boesch and } \\
\text { Boesch-Achermann } \\
2000\end{array}$ \\
\hline & 13.9-26.4 & MCP & Yearly 1992-2001 & $500 \times 500$ & $\begin{array}{l}\text { Lehman and Boesch } \\
\quad 2003\end{array}$ \\
\hline & 16.8 & MCP & 1996-1997 & $500 \times 500$ & Herbinger et al. 2001 \\
\hline Taï Middle & 12.1 & MCP & 1996-1997 & $500 \times 500$ & Herbinger et al. 2001 \\
\hline Taï South & 26.5 & MCP & 1996-1997 & $500 \times 500$ & Herbinger et al. 2001 \\
\hline Bossou & $15-20$ & & & & Humle 2011 \\
\hline Fongoli & $63<$ & & & & Pruetz 2006 \\
\hline Kasakati Z & 122 & & & & Izawa 1970 \\
\hline Kasakati L & 124 & & & & Izawa 1970 \\
\hline Ugalla & $470-560$ & & & & Ogawa et al. 2007 \\
\hline Mt. Assirik & 278-333 & & & & Baldwin et al. 1982 \\
\hline \multirow[t]{3}{*}{ Mahale K } & 10.4 & & & & Nishida 1979 \\
\hline & 10.5 & & & & $\begin{array}{l}\text { Kawanaka and } \\
\text { Nishida } 1977\end{array}$ \\
\hline & 6.2 & $\mathrm{MCP}^{\mathrm{c}}$ & 1980-1982 & $400 \times 400$ & Hasegawa 1987 \\
\hline \multirow[t]{5}{*}{ Mahale M } & 13.4 & & & & Nishida 1979 \\
\hline & 17 & & & & $\begin{array}{l}\text { Kawanaka and } \\
\text { Nishida } 1977\end{array}$ \\
\hline & 19.4 & $\mathrm{MCP}^{\mathrm{c}}$ & 1980-1982 & $400 \times 400$ & Hasegawa 1987 \\
\hline & 27.4 & MCP & 1994-2009 & $250 \times 250$ & This study \\
\hline & 13.9-22.2 & МСР & Yearly 1994-2009 & $250 \times 250$ & This study \\
\hline
\end{tabular}

a Unit-group before Kasakela group and Kahama group split

b MCP minimum convex polygon, GC grid cell. When MCP and other methods are given in one source, only MCP is shown here. Question marks indicate the method is not explicitly stated in the literature, but could be inferred from what is written

c Minimum convex polygon of outermost points of grids; thus estimated area size is larger than estimated by use of the method used in this study using center of grids 
Table 2 Comparison of monthly range sizes, overlaps, barycenter distances, and seasons

\begin{tabular}{lccccc}
\hline Month & $\begin{array}{c}\text { Mean range size } \\
\text { in MCP }\left(\mathrm{km}^{2}\right) \pm \\
\text { SD }\end{array}$ & $\begin{array}{c}\text { Overlap } \\
\text { index }\end{array}$ & $\begin{array}{c}\text { Mean barycenter dis- } \\
\text { tance }(\mathrm{km}) \pm \mathrm{SD}\end{array}$ & $\begin{array}{c}\text { Maximum barycenter } \\
\text { distance }(\mathrm{km})\end{array}$ & Season \\
\hline Jan & $7.09 \pm 1.23$ & 0.32 & $0.71 \pm 0.46$ & 2.22 & Saba \\
Feb & $5.91 \pm 2.74$ & 0.21 & $1.08 \pm 0.69$ & 2.65 & non-Saba \\
Mar & $5.42 \pm 2.41$ & 0.20 & $0.83 \pm 0.50$ & 2.37 & non-Saba \\
Apr & $5.22 \pm 2.04$ & 0.18 & $1.03 \pm 0.66$ & 2.99 & non-Saba \\
May & $7.87 \pm 3.37$ & 0.20 & $1.27 \pm 0.87$ & 3.71 & non-Saba \\
Jun & $8.06 \pm 3.69$ & 0.14 & $1.64 \pm 1.13$ & 5.46 & non-Saba \\
Jul & $8.99 \pm 3.39$ & 0.25 & $0.98 \pm 0.58$ & 2.77 & non-Saba \\
Aug & $10.38 \pm 3.50$ & 0.32 & $0.70 \pm 0.54$ & 2.00 & Saba \\
Sep & $9.65 \pm 2.20$ & 0.34 & $0.93 \pm 0.61$ & 2.62 & Saba \\
Oct & $8.57 \pm 2.05$ & 0.36 & $0.81 \pm 0.51$ & 2.35 & Saba \\
Nov & $7.00 \pm 1.56$ & 0.28 & $0.70 \pm 0.41$ & 1.69 & Saba \\
Dec & $6.93 \pm 2.81$ & 0.31 & $0.61 \pm 0.41$ & 2.17 & Saba \\
\hline
\end{tabular}

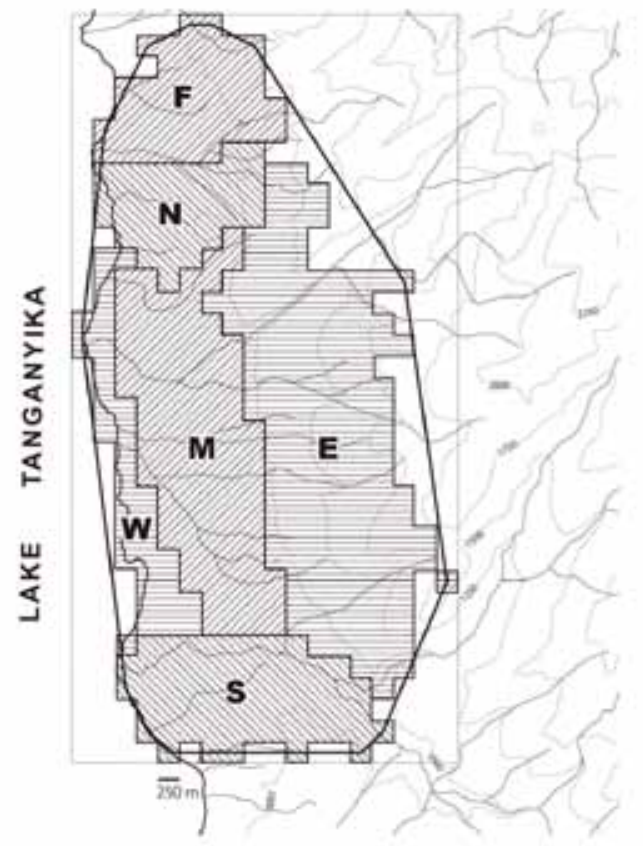

Fig. 1 Grids used by M group chimpanzees from 1994 to 2009 and the areas of blocks. The solid polygon shows the MCP. The size of the outermost rectangle (dotted line) is $8.75 \mathrm{~km} \times 4.5 \mathrm{~km}$

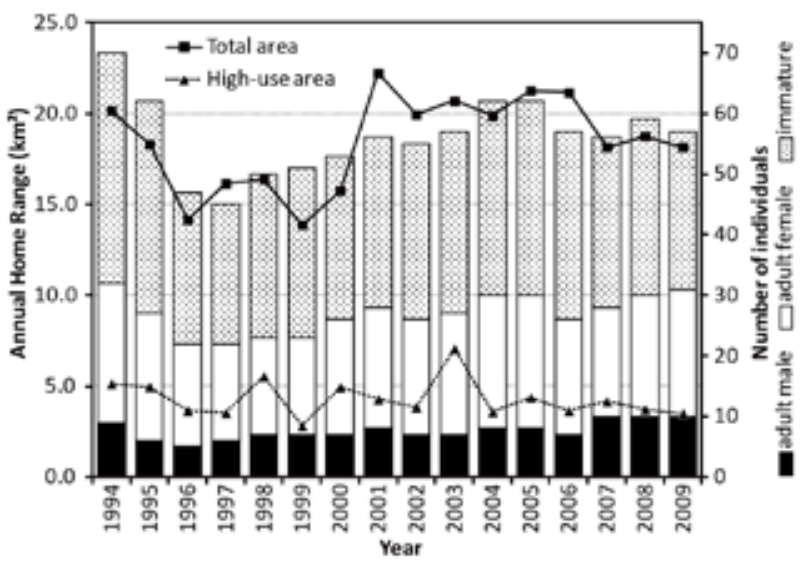

Fig. 2 Annual changes of the range size in MCP and the demography of M group 

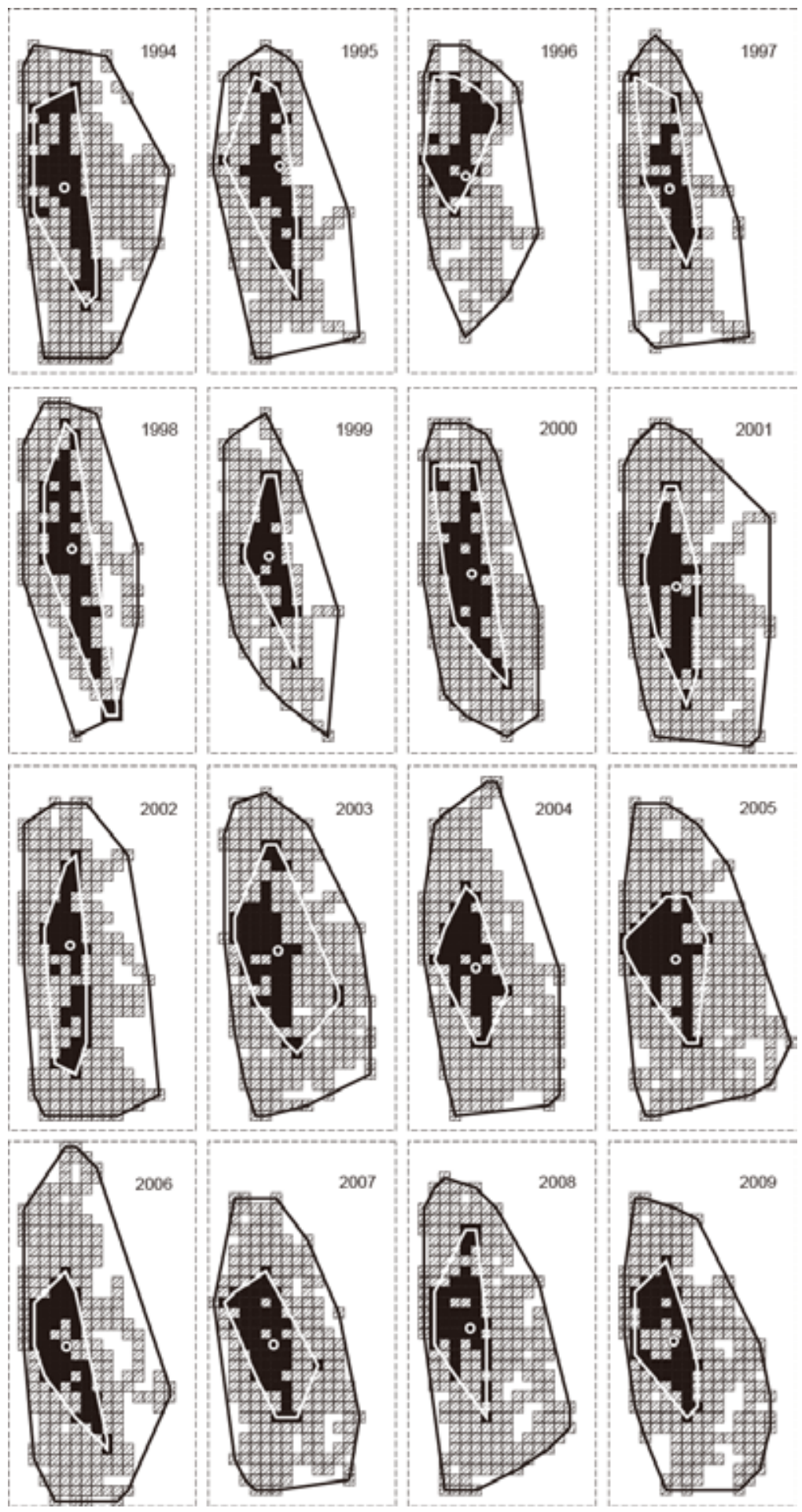

Fig. 3 Annual use by M group of $250 \mathrm{~m} \times 250 \mathrm{~m}$ grids. Black grids show high-use areas and grey grids show others. Black-lined polygons show total area of MCP and white-lined polygons show high-use area of MCP. White circles show barycenters. Dotted rectangles correspond to the rectangle shown in Fig. 1 


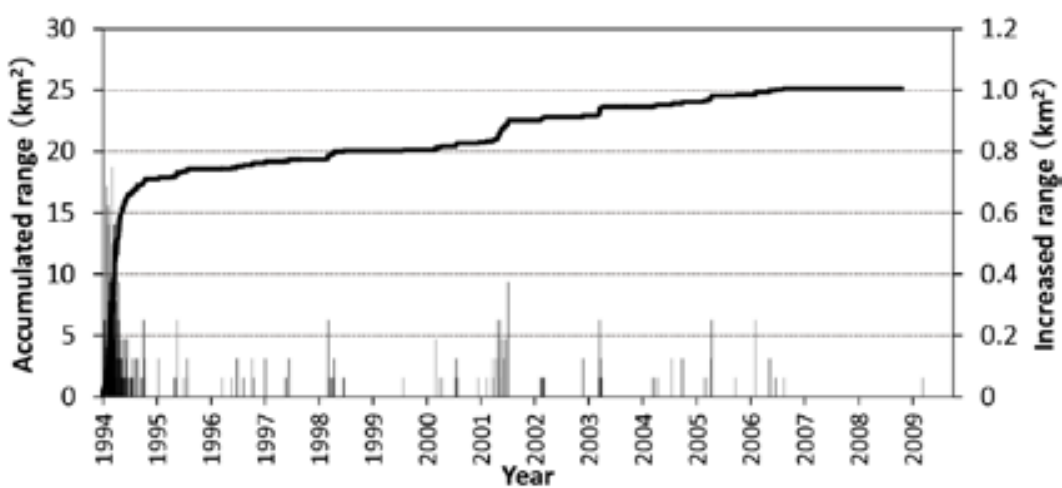

Fig. 4 Accumulation of areas used (thick line) and additional areas (thin vertical bars)

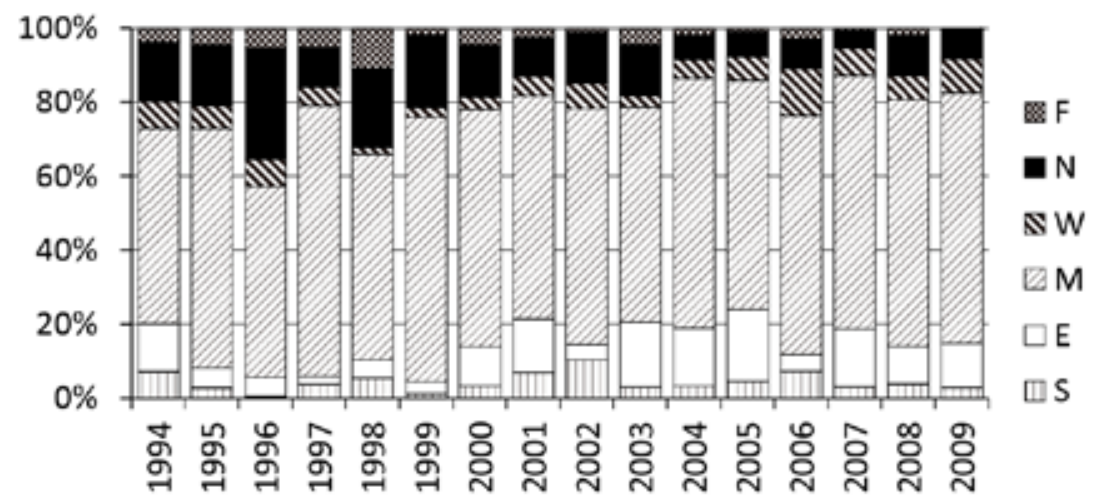

Fig. 5 Proportion of block utilization in different years

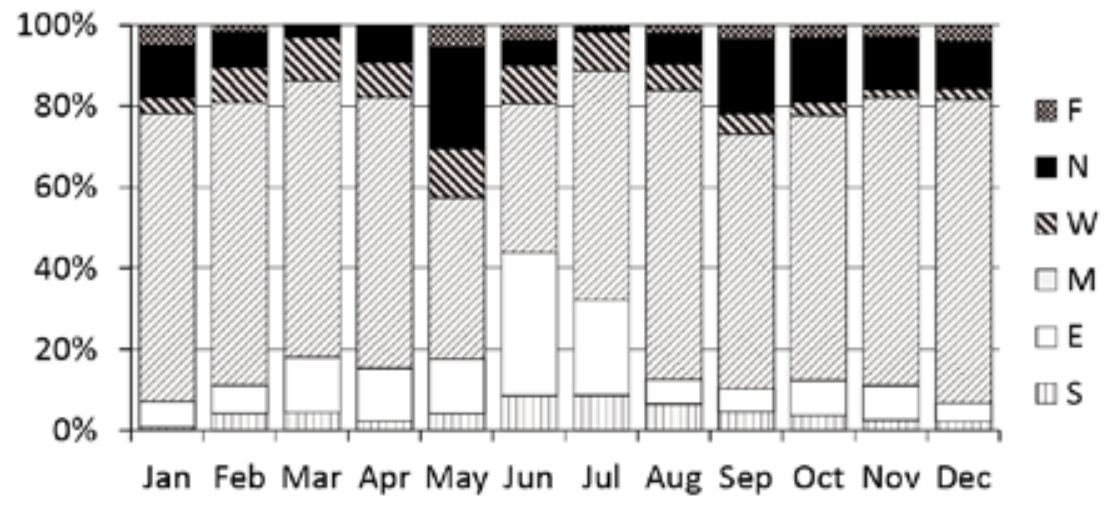

Fig. 6 Proportion of block utilization in different months 